\title{
False-positive human T-lymphotropic virus serology after intravenous immunoglobulin transfusion
}

\author{
Sophie Savary Bélanger MD, Douglas Fish MD, John Kim MSc PhD, Sandra Cohen MD
}

A cute biphenotypic leukemia was diagnosed in a 29-year-old man who had previously been well. The patient immediately started a course of intensive induction chemotherapy; however, the leukemia was refractory. The patient required a total of 3 courses of chemotherapy before achieving complete remission.

After his first course of chemotherapy, the patient felt weakness in both of his legs and numbness in his toes, and he was unable to urinate. A clinical examination showed upper motor neuron signs. The weakness improved with physiotherapy, but the numbness rapidly progressed during the second course of chemotherapy and subsequently stabilized with a sensory level at T5. The results of magnetic resonance imaging (MRI) of the patient's spine were normal, and an electroneuromyogram showed mixed polyneuropathy. The results of a lumbar puncture were unremarkable, leading us toward a diagnosis of toxic myelopathy, secondary to chemotherapy. We gave the patient $97.5 \mathrm{~g}(1 \mathrm{~g} / \mathrm{kg}$ body weight, intravenously) of immunoglobulins (Gamunex Biotherapeutics Inc.) empirically.

As part of the neurologic investigation, we performed serologic testing the day after the patient received the immunoglobulins; the results showed reactivity on an enzyme immunoassay for human T-lymphotropic virus (HTLV). Tests to confirm infection were done at the National Laboratory for HIV Reference Services: an INNO-LIA HTLV I/II Score assay (Innogenetics, Belgium) returned a positive result, and the results of an in-house radioimmunoprecipitation assay were indeterminate. The final interpretation of these tests was indeterminate (Table 1). A polymerase chain reaction (PCR) test for HTLV could not be done.

The patient and his parents were born in Canada. He was in a monogamous relationship, did not engage in high-risk behaviours and had never travelled to HTLV-endemic regions such as Asia. The result of repeat MRI of the patient's spine was normal. Baseline serologic testing for
HTLV, done when the patient's leukemia was diagnosed, was negative (Table 1). A serum sample taken 2 weeks before the positive screening test was retrospectively analyzed and was found to be negative for HTLV. Follow-up serologic testing on a whole blood sample collected 2 months later returned negative results, including PCR testing for the HTLV-I and HTLV-II tax gene sequences. Finally, a sample of cerebrospinal fluid collected at the 2-month follow-up was tested; the results of all investigations were negative.

Of note, the serum collected on the day after the patient received the immunoglobulin transfusion showed positive treponemal serology (Captia TA, Trinity Biotech), with negative nontreponemal serology (Rapid Plasma Reagin; Pulse Scientific Inc.) and negative confirmatory tests for treponemal organisms (Treponema pallidum particle agglutination assay [Fujirebio] and syphilis INNOLIA Score [Innogenetics]). Serologic testing for syphilis could not be done on the serum that had been collected before the immunoglobulin transfusion was given. However, 8 weeks after the transfusion, the results of an enzyme immunoassay for syphilis showed no reactivity (Table 1). Similarly, we saw positive results for antibodies to the hepatitis B core protein and surface antigen 5 weeks after the IVIg was given. The patient did not recall previous infection with hepatitis $\mathrm{B}$, nor did he recall having received the hepatitis B vaccine. Subse-

\section{KEY POINTS}

- All plasma-containing products can passively transfer antibodies, leading to false-positive serologic test results.

- Because commercially available intravenous immunoglobulin is a noncellular blood product, donors may not be tested for human T-lymphotrophic virus (HTLV).

- The possibility of passive transfer of antibodies to HTLV and other infectious agents through immunoglobulin transfusion should be considered when interpreting a positive test result.

- Infection can be confirmed by molecular testing for viral DNA or RNA (where feasible); alternatively, the serologic test can be repeated after 3 to 4 weeks, the approximate half-life of intravenous immunoglobulin.
Competing interests: None declared.

This article has been peer

Correspondence to:

Sophie Savary Bélanger, sophie.savary.belanger

CMAJ 2012. DOI:10.1503 /cmaj.120019 
quent analysis showed no reactivity to the hepatitis core protein and a lower titre for antibodies against the hepatitis B surface antigen (Table 1).

Given the patient's positive HTLV test result posttransfusion, his negative test results from 2 weeks before the transfusion and 2 months after, and the absence of risk factors for acquiring the infection, it is likely that the transfusion was responsible for a false-positive test result. The necessary regulatory authorities were notified, and we were advised that although Canadian blood donors are screened for antibodies to HTLV, there is no such screening for commercially available intravenous immunoglobulins.

Six months after the diagnosis of leukemia, the patient underwent allogeneic cord blood transplantation, a procedure that had been delayed until his HTLV status could be clarified. The patient is now in complete remission.

\section{Discussion}

Blood and blood-derived products are regulated by Health Canada and are administered by Cana- dian Blood Services or Héma-Québec. Donors are selected by screening for risk factors, and donations are subsequently subjected to laboratory investigations (Table 2). Such screening prevents most, if not all, transfusion-related infections with viral hepatitis, HIV, HTLV, syphilis, Chagas disease and West Nile virus. ${ }^{1}$

All labile blood products (packed red blood cells, platelets, granulocytes, plasma, cryoprecipitate, cryoprecipitate supernatant), with the exception of washed red blood cells, contain plasma and thus may transmit antibodies to infectious agents to which the donors were exposed. However, positive results on serologic testing are not expected for the infectious agents listed in Table 2 (with the exception of cytomegalovirus), because blood products showing positive serology are discarded.

\section{Intravenous immunoglobulins}

Intravenous immunoglobulins, made from large pooled quantities of human plasma, are used to treat numerous medical conditions, including Guillain-Barré syndrome, Kawasaki disease and

\begin{tabular}{|c|c|c|c|c|}
\hline \multirow[b]{2}{*}{ Test } & \multicolumn{4}{|c|}{ Result } \\
\hline & $\begin{array}{l}\text { Before } \\
\text { transfusion }\end{array}$ & $\begin{array}{l}\text { Immediately } \\
\text { after transfusion }\end{array}$ & $\begin{array}{c}5 \mathrm{wk} \\
\text { after transfusion }\end{array}$ & $\begin{array}{c}8 \mathrm{wk} \\
\text { after transfusion }\end{array}$ \\
\hline \multicolumn{5}{|l|}{ HTLV I/II } \\
\hline ELISA & Nonreactive* & Reactivet & NT & Nonreactive \\
\hline INNO-LIA & NT & Positive & NT & Negative \\
\hline RIPA & NT & Indeterminate & NT & NT \\
\hline \multicolumn{5}{|l|}{ Syphilis } \\
\hline ELISA & NT & Reactive & NT & Nonreactive \\
\hline $\begin{array}{l}\text { Rapid plasma } \\
\text { reagin }\end{array}$ & NT & Nonreactive & NT & Nonreactive \\
\hline $\begin{array}{l}\text { Treponema } \\
\text { pallidum particle } \\
\text { agglutination } \\
\text { assay }\end{array}$ & NT & Nonreactive & NT & Nonreactive \\
\hline INNO-LIA & NT & Negative & NT & Negative \\
\hline \multicolumn{5}{|l|}{ Hepatitis B } \\
\hline $\begin{array}{l}\text { Hepatitis B surface } \\
\text { antigen }\end{array}$ & Nonreactive & NT & NT & Nonreactive \\
\hline Anti-HBs & NT & NT & $\begin{array}{c}\text { Reactive } \\
\text { (titre } 719.6 \mathrm{IU} / \mathrm{L} \text { ) }\end{array}$ & $\begin{array}{c}\text { Reactive } \\
\text { (titre } 399.1 \mathrm{IU} / \mathrm{L}) \ddagger\end{array}$ \\
\hline Anti-HBC (total) & NT & NT & Reactive & Nonreactive§ \\
\hline \multicolumn{5}{|c|}{$\begin{array}{l}\text { Note: anti-HBC }=\text { antibody to hepatitis } B \text { core protein, anti-HBs }=\text { antibody to hepatitis } B \text { surface antigen, ELISA }=\text { enzyme-linked } \\
\text { immunosorbent assay, HTLV = human T-lymphotropic virus, INNO-LIA = commercially available line immunoassay, NT = not } \\
\text { tested, RIPA = radioimmunoprecipitation assay. } \\
\text { *HTLV I/II ELISA was repeated on a serum sample obtained } 2 \text { wk before transfusion and was still nonreactive. } \\
\text { tHTLV I/II ELISA was repeated on a serum sample obtained } 4 \mathrm{~d} \text { later and was still reactive. } \\
\text { ‡Anti-HBs serology was repeated } 4 \text { mo later and was still reactive (titre } 173.9 \text { IU/L). } \\
\text { §Anti-HBC serology was repeated } 4 \text { wk later and was still nonreactive. }\end{array}$} \\
\hline
\end{tabular}


necrotizing fasciitis. In hematology, intravenous immunoglobulins are commonly used to prevent infection in patients with hypogammaglobulinemia and to treat autoimmune cytopenias.

Although domestic immunoglobulins can be prepared from fractionated plasma, their availability is limited; most of the intravenous immunoglobulins distributed in Canada are obtained from different international pharmaceutical companies. Donors are screened for HIV, hepatitis $\mathrm{A}, \mathrm{B}$ and $\mathrm{C}$ viruses, and parvovirus 19. In addition, all plasma samples undergo various procedures (which are specific to each company) to eliminate/inactivate viruses. ${ }^{2}$ Manufacturers then add biochemical compounds to create products with specific $\mathrm{pH}$, isotonicity, stability and solubility. After infusion, the half-life of intravenous immunoglobulins is about 35 days. ${ }^{2}$ The results of our patient's serologic tests were consistent with this fact.

Passive transmission of antibodies has been previously reported via intravenous administration of immunoglobulins, resulting in falsepositive test results for a variety of infectious agents (cytomegalovirus, hepatitis B virus and syphilis) ${ }^{3,4}$ In addition to HTLV, our patient had false-positive test results for syphilis and hepatitis B, suggesting passive transfer of antibodies. The clinical implication of false-positive test results after the receiving intravenous immunoglobulins was suggested in a review of a Canadian trial, ${ }^{5}$ in which patients were denied potentially beneficial treatment (rituximab) for acute immune thrombocytopenic purpura on the basis of false-positive, passively transferred antibodies to the hepatitis B core protein.

\section{Transmission of HTLV antibodies}

Two patients from Australia had positive test results for HTLV after receiving intravenous immunoglobulins as prophylaxis following allogeneic stem cell transplantation. ${ }^{6}$ It is worth noting that the risk of transmission of HTLV, an intracellular virus similar to cytomegalovirus, through noncellular blood products (plasma, cryoprecipitates, cryoprecipitate supernatant and immunoglobulins) is considered null. ${ }^{1}$ However, these products may transmit antibodies to these viruses in the absence of screening.

False-positive results for serologic tests for infectious agents such as HTLV can cause substantial anxiety, result in further diagnostic tests and delay life-saving procedures. HTLV is associated with adult $\mathrm{T}$ cell leukemia/lymphoma and tropical spastic paraparesis, a degenerative neuromyelopathy, which was particularly worrisome in light of our patient's neurologic symptoms.

Although passive transfer of antibodies against a variety of viral and bacterial agents has been well-documented, the phenomenon may not be considered when interpreting the results of serologic tests in the laboratory or in practice. Physicians and laboratory professionals should be aware of the risk of passive acquisition of antibodies following a transfusion of blood products, particularly one involving intravenous immunoglobulins. For this reason, such results should be interpreted with caution to avoid unnecessary diagnostic and clinical procedures. Testing to confirm the presence of viral RNA or DNA using molecular methods such as PCR may not always be feasible. Instead, serologic tests can be repeated at a later date, once the

Table 2: Pathogens for which donor blood and blood-derived products are tested in Quebec

\begin{tabular}{|c|c|c|c|}
\hline \multirow[b]{2}{*}{ Pathogen } & \multicolumn{3}{|c|}{ Target } \\
\hline & Antibody & Antigen & Nucleic acid \\
\hline HIV $1 / 2$ and group $O$ & $\checkmark$ & NA & NA \\
\hline HIV 1 & NA & NA & $\checkmark$ \\
\hline Hepatitis B virus & $\sqrt{*}$ & $\checkmark$ & $\checkmark$ \\
\hline Hepatitis C virus & $\checkmark$ & NA & $\checkmark$ \\
\hline HTLV I/II & $\checkmark$ & NA & NA \\
\hline Syphilis & $\checkmark$ & NA & NA \\
\hline Cytomegalovirus† & $\checkmark$ & NA & NA \\
\hline West Nile virusł & NA & NA & $\checkmark$ \\
\hline Trypanosoma cruzi§ & $\checkmark$ & NA & NA \\
\hline \multicolumn{4}{|c|}{$\begin{array}{l}\text { Note: Adapted from Circular of information for the use of labile blood products. Saint-Laurent (QC): Héma-Québec; 2010. p. } \\
\text { HTLV = human T-lymphotropic virus, NA = not applicable. } \\
\text { *Test to detect antibody to hepatitis B core protein. } \\
\text { tDone on a portion of the Héma-Québec inventory. } \\
\text { fOnly done between June } 1 \text { and Nov. } 30 \text {, or if donor has travelled outside of Canada in the previous } 56 \text { days. } \\
\text { §Test done if donor presents risk factors for Chagas disease. }\end{array}$} \\
\hline
\end{tabular}


antibodies are expected to have been eliminated (depending on the half-life of the blood product). If available, the transfused blood product should also be tested.

Transfusion services and clinical laboratories should be engaged in close communication. Communication between the laboratory professional and the clinician concerning the potential effect of transfused blood products on serologic testing can minimize the misinterpretation of test results and result in better patient care.

\section{References}

1. Circular of information for the use of labile blood products. LSC-SPE-006a Version 7. Québec (QC): Héma-Québec; 2010.

2. Plasma protein products information. Ottawa $(\mathrm{ON})$ : Canadian Blood Services. Available: www.bloodservices.ca/centreapps /internet/uw_v502_mainengine.nsf/page/E_PlasmaProducts (accessed 2012 Jan. 5).

3. Constable SA, Parry CM, Enevoldson TP, et al. Positive serological tests for syphilis and administration of intravenous immunoglobulin. Sex Transm Infect 2007;83:57-8.

4. Rossi KQ, Nickel JR, Wissel ME, et al. Passively acquired treponemal antibody from intravenous immunoglobulin therapy in a pregnant patient. Arch Pathol Lab Med 2002;126:1237-8.

5. Arnold DM, Crowther MA, Meyer RM et al. Misleading hepatitis B test results due to intravenous immunoglobulin administration: implications for a clinical trial of rituximab in immune thrombocytopenia. Transfusion 2010;50:2577-81.

6. Kennedy GA, Cummings J, Durrant ST. Potential impact of AUSFTA on Australia's blood supply [letter]. Med J Aust 2007; 186:427.
Affiliations: From the Faculté de médecine (Bélanger, Fish, Cohen), Université de Montréal, Montréal, Que.; the Service d'hématologie (Fish, Cohen), Hôpital Maisonneuve-Rosemont, Montréal, Que.; and the National Laboratory for HIV Reference Services (Kim), Ottawa, Ont.

Contributors: All of the authors contributed to the conception and design of the article, revised it for important intellectual content and approved the final version submitted for publication.

Acknowledgement: The authors acknowledge the assistance and guidance of Dr. Annie-Claude Labbé, medical microbiologist, who proposed the subject of this publication and was extremely helpful at all stages of writing and revising the manuscript.

The section Cases presents brief case reports that convey clear, practical lessons. Preference is given to common presentations of important rare conditions, and important unusual presentations of common problems. Articles start with a case presentation (500 words maximum), and a discussion of the underlying condition follows (1000 words maximum). Visual elements (e.g., tables of the differential diagnosis, clinical features or diagnostic approach) are encouraged. Written consent from patients for publication of their story is a necessity and should accompany submissions. See information for authors at www.cmaj.ca. 